\title{
Towards Nearly-Zero Energy Buildings: HVAC System Performance in the Expected Operative Scenarios of Turin Energy Centre
}

\author{
Antonio Mangogna ${ }^{1}$, Daniela Valagussa ${ }^{2}$, Temitope Akintola ${ }^{3}$, Matteo Arietti ${ }^{4}$, Salvatore Cicero ${ }^{5}$, \\ Federica Mordillo ${ }^{6}$, Anna Pagani ${ }^{7}$, Rachele Sipione ${ }^{8}$, Stefano Paolo Corgnati ${ }^{9}$, \\ ${ }^{1,2}$ Politecnico di Milano - Alta Scuola Politecnica, ${ }^{3,4,5,6,7,8}$ Politecnico di Torino - Alta Scuola Politecnica, \\ ${ }^{9}$ Politecnico di Torino
}

\begin{abstract}
This paper shows the process of minimization of delivered energy, primary energy consumption and carbon dioxide emissions for the Turin Energy Centre, a building to be realized in the city of Turin in 2015 . The optimization is divided into two steps, firstly operating on the distribution of the functions of spaces, the loads and the HVAC systems in the building, and then, chosen the functional scenario, modifying the generation system. The result is the combination of building's operative functions and generation systems that minimizes consumptions and emissions, neglecting accumulation and partial load dynamics.
\end{abstract}

Keywords - Energy Centre, HVAC, nZEB, energy efficiency.

\section{INTRODUCTION}

The reduction of energy consumption in buildings became fundamental in the EU regulatory framework, with the EU 2020-20 strategy and the European Directive on the Energy Performance of Buildings (EPBD); therefore, the attention to energy efficiency topics is nowadays compulsory. Energy Centres could be the best institutions for researching new energy-efficient technologies and spreading information about this topic: the building itself has to be a symbol of the change, towards Nearly Zero Energy Building (nZEB) and Nearly Zero Carbon Building concepts, using also on-site renewable energy sources.

Within the work developed in the multidisciplinary project of ASP (Alta Scuola Politecnica) of Polytechnic of Milan and Turin, a general overview of the most significant examples of international Energy Centres was performed in order to get information about the characteristics of the energy systems in this kind of buildings. Then, the focus was specifically made on the new institute located in Turin: the Turin Energy Centre (TEC), now at its final design stage.

In this activity, five functional scenarios were defined. In these scenarios, each activity is located in a room with a suitable HVAC system. Then, different generation solutions were studied and coupled with the scenarios in order to find the best combination and optimize it, with the aim of reducing energy consumption and carbon emissions. The analysis started from the project at the present stage, in which the architectural characteristics and the basic concept of the energy system were proposed.
A 3D model of the building was prepared with SketchUpOpenStudio and all the technological and system characteristics were added with the OpenStudio plug-in (additional data, not defined in the documentation of the project, were taken from Standard ASHRAE 189.1 - 2009 [1]). The dynamic simulations were performed using EnergyPlus (U.S. Department of Energy) and some additional calculations were developed with Excel spreadsheets.

\section{THE BUILDING}

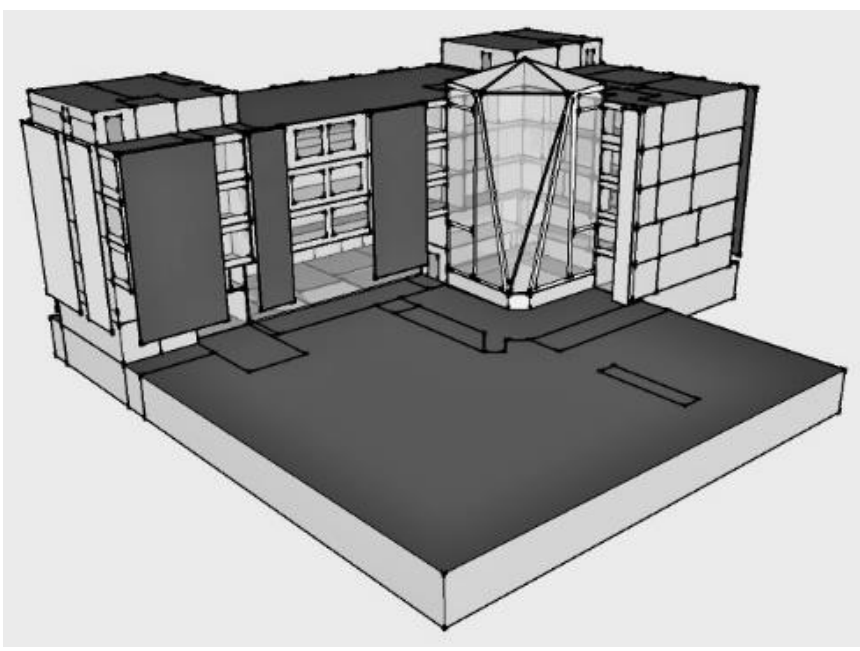

Fig. 1. Turin Energy Centre SketchUp-OpenStudio 3D model.

Turin Energy Centre (Fig. 1) is a new building to be constructed in the city of Turin (Italy, $45^{\circ} 07^{\prime} \mathrm{N} ; 7^{\circ} 43^{\prime} \mathrm{E} ; 239$ $\mathrm{m}$ asl). It is L-shaped with a glass volume facing south at the intersection of the wings; the roof is flat and accessible. The net surface is $6,290 \mathrm{~m}^{2}$ distributed on five floors [2], one of which is in the basement. The indoor environment hosts laboratories, offices, a conference room, exhibition areas and a refreshment service. 


\section{A. The envelope}

Ventilated façades and curtain walls characterize the envelope. The opaque surfaces [3] are vibrocompressed concrete block walls (where fire resistance is required, e.g. laboratories) and stratified dry walls; external insulation is provided by double-density stone wool or extruded polystyrene (XPS) panels. The cladding of the ventilated façade consists of aluminium corrugated sheets and staves placed $50 \mathrm{~cm}$ out of the wall. The glasses [4] of the mullion and transom curtain wall present different coatings in accordance with the exposition: on the north-east and north-west sides they are low-emission, while on the south-east and south-west sides they are selective. The average thermal transmittance of the whole building is 0.43 $\mathrm{W} / \mathrm{m}^{2} \mathrm{~K}[5]$.

The bearing structure is made of reinforced concrete elements; the floors, made in reinforced concrete, provide the building with the thermal capacity not given by the low-surfacemass dry walls.

\section{B. Energyneeds}

The energy needs of the building for heating and cooling were calculated and taken as a starting point for the following analysis.

TABLE I

SET POINTS

\begin{tabular}{|l|c|l|c|}
\hline \multicolumn{2}{|c|}{ Winter } & \multicolumn{2}{c|}{ Summer } \\
\hline Temperature & $20^{\circ} \mathrm{C}$ & Temperature & $26^{\circ} \mathrm{C}$ \\
\hline $\begin{array}{l}\text { Relative } \\
\text { humidity }\end{array}$ & (Average) $50 \%$ & $\begin{array}{l}\text { Relative } \\
\text { humidity }\end{array}$ & (Average) $50 \%$ \\
\hline \multicolumn{3}{|c|}{ Ventilation } & $\mathrm{m}^{3} / \mathrm{h}$ pers \\
\hline Laboratories, offices, conference room & 34 & $\mathrm{~m}^{3} / \mathrm{h}$ pers \\
\hline Bar and restaurant & 25 & $\mathrm{~m}^{3} / \mathrm{h} \mathrm{m}^{2}$ \\
\hline Exhibition areas & 1 & $\mathrm{~m}^{3} / \mathrm{h} \mathrm{m}^{2}$ \\
\hline Corridors and stairs & 1 & \\
\hline
\end{tabular}

TABLE II

ENERGY NEEDS

\begin{tabular}{|l|l|l|}
\hline Heating & 127.089 & MWh \\
\hline Cooling & 140.164 & MWh \\
\hline
\end{tabular}

Table I lists the set point used, taken from the technical report [2]: they are met only when HVAC systems are on, that is 16 hours/day [2], from 6 a.m. to 10 p.m. Table II describes the results. In the following analysis, also $7.258 \mathrm{MWh} /$ year for Domestic Hot Water (DHW; $109.5 \mathrm{~m}^{3} /$ year) was considered.

\section{THE FUNCTIONS}

At the present stage of design, in the building there are rooms with various functions that can be grouped into three main categories: laboratories, services and working rooms. Different crowd levels, lighting specifications and other particular needs characterize each function, as shown in Table III.

The ratio between the surfaces allocated to each function defines the kind of activity the overall energy centre will have (in the computation, the areas used as corridors, stairs and toilets were excluded).
TABLE III

FUNCTIONS

\begin{tabular}{|c|c|c|c|c|c|}
\hline $\begin{array}{c}\text { Main } \\
\text { category }\end{array}$ & Function & $\begin{array}{c}\text { Crowd } \\
\text { level } \\
\text { (people/m²) } \\
{[1]}\end{array}$ & $\begin{array}{c}\text { Lighting } \\
\text { needs (lux) } \\
{[6]}\end{array}$ & $\begin{array}{c}\text { Electrical } \\
\text { equipment } \\
\left(\mathrm{W} / \mathbf{m}^{2}\right)[6]\end{array}$ & $\begin{array}{c}\text { Gas } \\
\text { equipment } \\
\left(\mathbf{W} / \mathbf{m}^{2}\right)\end{array}$ \\
\hline Laboratories & Laboratory & 0.02 & 200 & 179.0 & - \\
\hline \multirow[t]{2}{*}{ Services } & $\begin{array}{l}\text { Bar and } \\
\text { restaurant }\end{array}$ & 0.54 & 300 & 55.00 & 8.5 \\
\hline & Exhibition & 0.01 & 200 & 41.44 & - \\
\hline \multirow{2}{*}{$\begin{array}{l}\text { Working } \\
\text { rooms }\end{array}$} & Office & 0.06 & 400 & 7.642 & - \\
\hline & Conf. room & 0.54 & 500 & 3.983 & - \\
\hline
\end{tabular}

TABLE IV

FUNCTIONAL SCENARIOS

\begin{tabular}{|c|c|c|c|c|c|c|}
\hline \multirow[b]{2}{*}{ Scenario } & \multirow{2}{*}{$\begin{array}{l}\text { Kind of } \\
\text { activity }\end{array}$} & \multirow[b]{2}{*}{ Labs } & \multicolumn{2}{|c|}{ Services } & \multicolumn{2}{|c|}{ Working rooms } \\
\hline & & & $\begin{array}{c}\text { Bar } \\
\text { restaurant }\end{array}$ & Exhibition & Office & $\begin{array}{l}\text { Conf. } \\
\text { room }\end{array}$ \\
\hline 1 & $\begin{array}{l}\text { Designed } \\
\text { functions }\end{array}$ & $25 \%$ & $10 \%$ & $20 \%$ & $40 \%$ & $5 \%$ \\
\hline 2 & $\begin{array}{l}\text { Low-tech } \\
\text { educational }\end{array}$ & $20 \%$ & $10 \%$ & $20 \%$ & $45 \%$ & $5 \%$ \\
\hline 3 & $\begin{array}{l}\text { High-tech } \\
\text { educational }\end{array}$ & $50 \%$ & $10 \%$ & $10 \%$ & $25 \%$ & $5 \%$ \\
\hline 4 & $\begin{array}{l}\text { Low-tech } \\
\text { business } \\
\text { and social }\end{array}$ & $20 \%$ & $15 \%$ & $25 \%$ & $35 \%$ & $5 \%$ \\
\hline 5 & $\begin{array}{l}\text { High-tech } \\
\text { business } \\
\text { and social }\end{array}$ & $40 \%$ & $10 \%$ & $20 \%$ & $25 \%$ & $5 \%$ \\
\hline
\end{tabular}

Five different functional scenarios were identified: Table IV presents them by the indication of the percentages of the useful surfaces assigned to each category.

"Educational" is an activity characterized by courses and events related to university and professional training, whereas "business and social" means activities of product testing and marketing for companies.

\section{THE DESIGNED SYSTEM}

As said in the introduction, each function is located in a room provided with a suitable HVAC system [7]:

- In the offices, there are ceiling panels, which perform mainly for cooling rather than for heating; in fact, in an insulated building with large transparent surfaces, eliminating sensible heat in summer is usually more critical than providing it during winter. In spite of this fact, in the exhibition and refreshment areas, the radiant floor is preferable due to architectural reasons. All these spaces are also provided with a primary air system that controls the indoor air quality.

- In the laboratories, the previous technologies were considered to be unsuitable: the ceiling panels due to the height of the rooms $(7.58 \mathrm{~m})$ and the radiant floor because of the equipment that might need specific basements. Therefore, unit heaters were chosen to provide the thermal comfort. 
- The conference room is characterized by discontinuous use and high crowd level, so it has an independent climatization with a dedicated air only plant.

The climatic and environmental regulation [2], with $1^{\circ} \mathrm{C}$ proportional band, allows ensuring comfortable conditions in each room, reducing the energy consumption.

As regards the generation system [7], the Turin Energy Centre was conceived with double equipment both for cooling and for heating. A waterbed hot water heat pump, which is supposed to supply hot water at $50^{\circ} \mathrm{C}$ and cold water at $7{ }^{\circ} \mathrm{C}$, is supported by a connection to the district heating. The latter is linked to the heating circuit via heat exchangers and to the cooling system via an absorption refrigerator.

For the needs of analysis, the hypothesis was made that only the district heating is used for heating (exchange efficiency 0.963 [7]) and only the heat pump for cooling (EER 5.64 [7]). Table V shows the results of the simulations in which the "designed system" (DES) was coupled with all the previously defined functional scenarios.

For the plant components used in this and in other following systems, see table XII at the end of the paper.

\section{THE REFERENCE SYSTEM}

In order to test the quality of the designed system, it was compared with a more conventional system, named "reference system" (REF).

In the REF, an air system feeds all the conditioned zones of the building and its generation system is composed as follows: a fixed dry bulb economizer, an electrical steam humidifier, a two-speed cooling coil $(\mathrm{COP}=4)$, a gas coil reheat (burner efficiency $=0.9$ ) and a variable volume fan (fan efficiency = 0.7 ; pressure rise $=850 \mathrm{~Pa}$; motor efficiency $=0.95$ ). Table $\mathrm{V}$ shows the results obtained.

\section{COMPARISON AND COMMENTS}

In this paragraph, it is described how different functional scenarios influence the consumption of the building, in terms of delivered energy, primary energy supply and $\mathrm{CO}_{2}$ emissions. Fig. 2 and Fig. 3 show the total annual delivered energy divided per end uses.

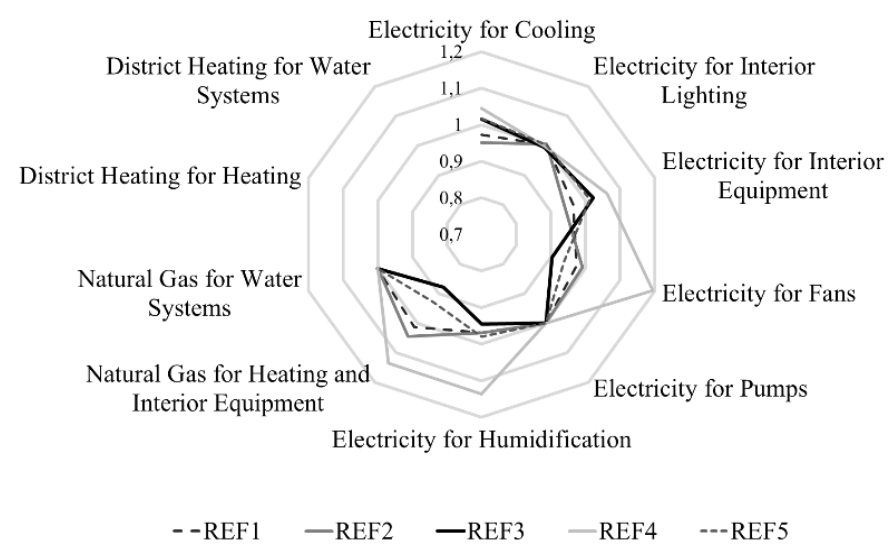

Fig. 2. Delivered energy (REF system) normalized on REF average (MWh/MWh average).

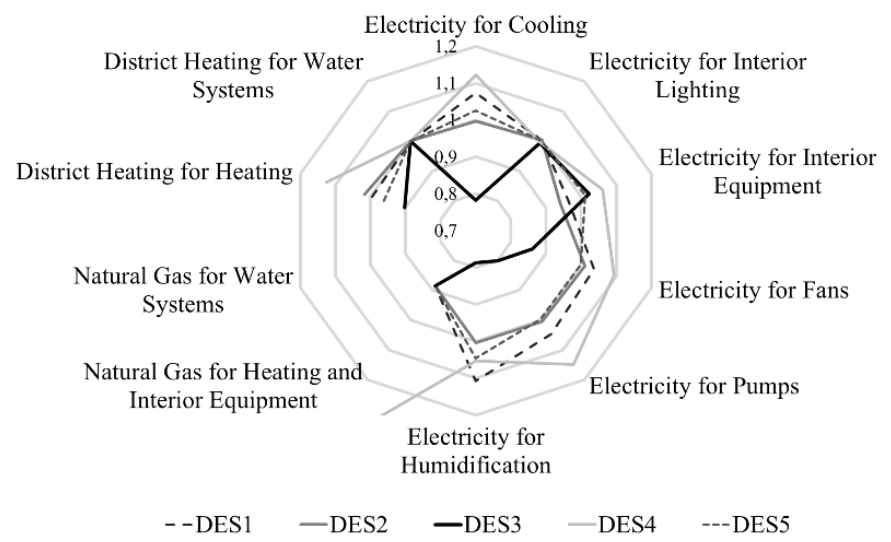

Fig. 3. Delivered energy (DES system) normalized on DES average (MWh/MWh average).

TABLE V

DELIVERED ENERGY REF AND DES (ANNUAL BASE)

\begin{tabular}{|c|c|c|c|c|c|c|c|c|c|c|c|c|c|c|c|}
\hline & \multicolumn{6}{|c|}{ Electricity (MWh) } & \multicolumn{3}{|c|}{ Natural gas (MWh) } & \multicolumn{2}{|c|}{\begin{tabular}{c|} 
District \\
heating (MWh)
\end{tabular}} & \multirow{2}{*}{ 휼 } & \multirow{2}{*}{ 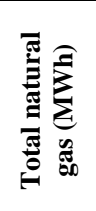 } & \multirow{2}{*}{ 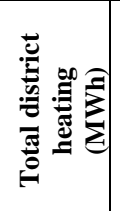 } & \multirow{2}{*}{ 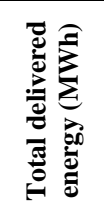 } \\
\hline & :̊n & 离 & 高室 & 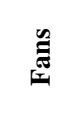 & $\stackrel{\tilde{E}}{\Xi}$ & I. & 苞 & 高富 & 离参 & 㫭 & 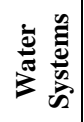 & & & & \\
\hline REF1 & 72.42 & 195.46 & 495.56 & 46.16 & 0.06 & 138.50 & 195.84 & 0.64 & 8.07 & 0 & 0 & 948.14 & 204.55 & 0 & 1152.69 \\
\hline REF2 & 70.84 & 195.86 & 483.50 & 46.93 & 0.06 & 138.53 & 201.90 & 0.64 & 8.07 & 0 & 0 & 935.72 & 210.61 & 0 & 1146.31 \\
\hline REF3 & 75.60 & 193.68 & 525.78 & 42.78 & 0.06 & 135.09 & 169.73 & 0.64 & 8.07 & 0 & 0 & 973.00 & 178.44 & 0 & 1151.44 \\
\hline REF4 & 77.84 & 194.25 & 545.83 & 56.61 & 0.06 & 162.46 & 219.04 & 1.06 & 8.07 & 0 & 0 & 1037.06 & 228.16 & 0 & 1265.22 \\
\hline REF5 & 75.77 & 195.29 & 520.28 & 44.43 & 0.06 & 140.06 & 179.31 & 0.64 & 8.07 & 0 & 0 & 975.89 & 188.02 & 0 & 1163.92 \\
\hline DES1 & 49.78 & 195.46 & 495.56 & 47.43 & 5.04 & 138.50 & 0 & 0.64 & 0 & 188.00 & 7.54 & 931.75 & 0.64 & 195.54 & 1127.94 \\
\hline DES2 & 46.21 & 195.86 & 483.50 & 46.21 & 4.84 & 125.54 & 0 & 0.64 & 0 & 192.14 & 7.54 & 902.14 & 0.64 & 199.68 & 1102.47 \\
\hline DES3 & 36.24 & 193.68 & 525.81 & 39.37 & 3.86 & 98.49 & 0 & 0.64 & 0 & 170.38 & 7.54 & 897.42 & 0.64 & 177.92 & 1076.00 \\
\hline DES4 & 52.02 & 194.25 & 545.83 & 49.98 & 5.54 & 131.75 & 0 & 1.06 & 0 & 212.39 & 7.54 & 979.33 & 1.06 & 219.93 & 1200.33 \\
\hline DES5 & 47.55 & 195.29 & 520.28 & 45.66 & 4.81 & 130.88 & 0 & 0.64 & 0 & 181.60 & 7.54 & 944.44 & 0.64 & 189.14 & 1134.25 \\
\hline
\end{tabular}


It is clearly noticeable that scenario 3 (high-tech educational) presents the minimum consumption in different fields, from humidification to heating and cooling. This is due to the large surface dedicated to laboratories, which have a very low crowd level. In fact, less people means less primary air to be handled and less sensible heat loads to remove in summer. Also, the electricity required for fans is lower than in other scenarios because of the smaller primary air flow rate. These reasons explain the big difference between scenarios 3 and 4 (low-tech business and social, only $20 \%$ laboratories) in the mentioned fields.

As regards electricity consumption, scenarios 3 and 4 have the highest surface percentages destined to laboratories (3) or to bar and restaurant (4) (functions with high electrical loads, mainly due to the overhead travelling crane in labs and the refrigerating room in the bar and restaurant), therefore consumptions for electrical interior equipment are high.

The analysis of the functions hosted in the building is essential for the correct sizing of the systems. However, it would be better to suppose dynamic situations, in which building functions and crowding vary during the year, in order to evaluate the response to load variations.

At this stage, it is convenient to find the best scenario, from the energy point of view, in order to optimize it in the second part of the study. The 'best scenario' should be the coupling function-system that requires the lowest delivered energy. As it was previously mentioned, total primary energy consumption and $\mathrm{CO}_{2}$ emissions related to each scenario should be also compared. Table VI shows the conversion factors used.

TABLE VI

CONVERSION FACTORS

\begin{tabular}{|l|c|c|}
\hline & $\begin{array}{c}\mathbf{C O}_{2} \text { conversion } \\
\text { factor }(\mathbf{k g} / \mathbf{M W h})\end{array}$ & $\begin{array}{c}\text { Primary energy } \\
\text { conversion factor }\end{array}$ \\
\hline Natural Gas & $203[8]$ & $1.000[9]$ \\
\hline Electricity & $470[8]$ & $2.500[9]$ \\
\hline District Heating & $140.5[5]$ & $0.536[5]$ \\
\hline
\end{tabular}

In Fig. 4 and Fig. 5 we can see that DES3 (the high-tech educational asset coupled with the designed plant) is the combination characterized by the highest energy savings and the lowest $\mathrm{CO}_{2}$ emissions.

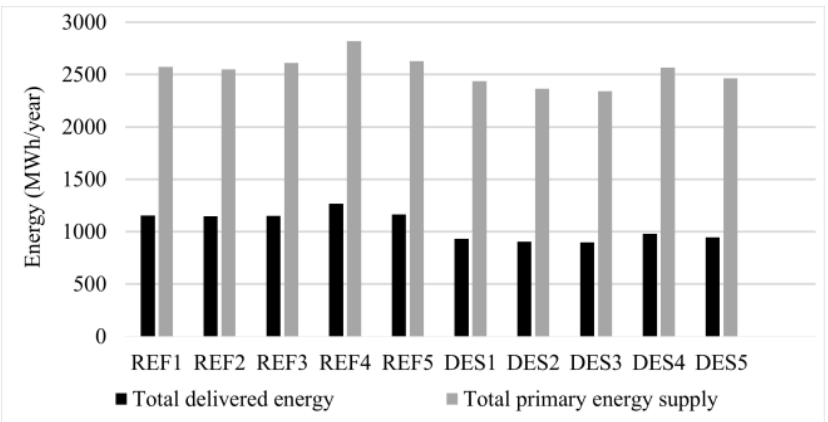

Fig. 4 Total delivered energy and total primary energy supply.

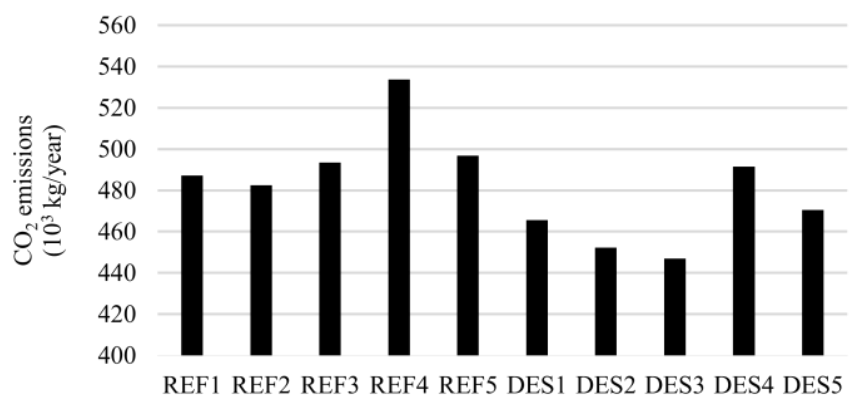

Fig. 5. Total $\mathrm{CO}_{2}$ emission.

Even regarding primary energy savings and $\mathrm{CO}_{2}$ emissions, scenario DES3 proves to be the best. This is mainly due to the fact that among the functional scenarios it requires the lowest delivered energy, and the DES system relies on district heating and on a waterbed convertible heat pump, instead of gas burners and cooling coils used in REF systems.

The following part of the paper refers to DES3 scenario for further optimization.

\section{OPTIMIZATION}

Starting from DES3 scenario, three optimization strategies were developed: two focused on on-site renewable sources and one based on a cogenerator.

\section{A. Approach 1: renewable sources}

The renewable sources available on site are the aquifer (assumed at constant temperature during the year) and the sun; therefore the first scheme adopted entails the use of a waterbed hot water heat pump (for heating, cooling and DHW) matched with a photovoltaic (PV) system. The total surface to allocate to panels was calculated in order to provide the $25 \%, 50 \%, 75 \%$ and $100 \%$ of the electricity required for the heat pump (respectively DES3 25\% PV, DES3 50\% PV, DES3 75\% PV; DES3 100\% PV); delivered energy will cover the other electrical needs of the building. The calculations is based on the choice of a proper inclination of the panels (the one that maximizes the cumulative annual energy production, $38.85^{\circ}$ ) and of an adequate distance between the strings in order to avoid overshadowing $(4.7 \mathrm{~m}$ ); the PV panels considered (ALEO S18K255 [10]) deliver a $255 \mathrm{~W}$ power each, under standard test conditions.

The second strategy consists of the use of solar thermal panels for the production of hot water that will power the absorption refrigerator and feed the heating and the DHW system. Also in this case, the total surface allocated to panels was calculated in order to cover the $25 \%, 50 \%, 75 \%$ and $100 \%$ of the thermal needs previously described (respectively DES3 $25 \%$ ST, DES3 50\% ST, DES3 75\% ST; DES3 100\% ST). Evacuated-tube collectors providing water at $110^{\circ} \mathrm{C}$ were considered; they are characterized by an efficiency of 0.4 , with $400 \mathrm{~W} / \mathrm{m}^{2}$ irradiance, and of 0.6 , with $1000 \mathrm{~W} / \mathrm{m}^{2}$ irradiance. 
TABLE VII

DELIVERED ENERGY WITH PV AND ST (ANNUAL BASE)

\begin{tabular}{|c|c|c|c|c|c|c|c|c|c|c|c|c|}
\hline & \multicolumn{6}{|c|}{ Electricity (MWh) } & \multicolumn{3}{|c|}{ Natural gas (MWh) } & \multicolumn{2}{|c|}{$\begin{array}{c}\text { District heating } \\
\text { (MWh) }\end{array}$} & \multirow[b]{2}{*}{$\begin{array}{l}\underset{\Xi}{\Xi} \\
\stackrel{\Xi}{\Xi} \\
\stackrel{\Xi}{\Xi}\end{array}$} \\
\hline & ن & 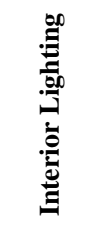 & 总 & $\underset{\Xi}{\tilde{I}}$ & $\stackrel{\mathscr{E}}{E}$ & 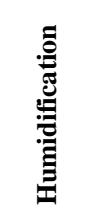 & 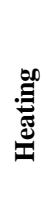 & 总 & 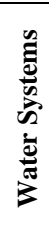 & & 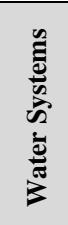 & \\
\hline DES3 25\% PV & 27.18 & 193.68 & 525.78 & 39.37 & 3.86 & 98.49 & 0 & 0.64 & 0 & 126.15 & 5.58 & 178.01 \\
\hline DES3 25\% ST & 27.18 & 193.68 & 525.78 & 39.37 & 3.86 & 98.49 & 0 & 0.64 & 0 & 126.15 & 5.58 & 314.69 \\
\hline DES3 50\% PV & 18.12 & 193.68 & 525.78 & 39.37 & 3.86 & 98.49 & 0 & 0.64 & 0 & 81.92 & 3.62 & 341.69 \\
\hline DES3 50\% ST & 18.12 & 193.68 & 525.78 & 39.37 & 3.86 & 98.49 & 0 & 0.64 & 0 & 81.92 & 3.62 & 627.19 \\
\hline DES3 75\% PV & 9.06 & 193.68 & 525.78 & 39.37 & 3.86 & 98.49 & 0 & 0.64 & 0 & 37.69 & 1.67 & 460.81 \\
\hline DES3 75\% ST & 9.06 & 193.68 & 525.78 & 39.37 & 3.86 & 98.49 & 0 & 0.64 & 0 & 37.69 & 1.67 & 924.78 \\
\hline DES3 $100 \%$ PV & 0 & 193.68 & 525.78 & 39.37 & 3.86 & 98.49 & 0 & 0.64 & 0 & 0 & 0 & 630.94 \\
\hline DES3 100\% ST & 0 & 193.68 & 525.78 & 39.37 & 3.86 & 98.49 & 0 & 0.64 & 0 & 0 & 0 & 1232.44 \\
\hline
\end{tabular}

TABLE VIII

DELIVERED ENERGY PV DE $=0($ ANNUAL BASE $)$

\begin{tabular}{|c|c|c|c|c|c|c|c|c|c|c|c|c|}
\hline & \multicolumn{6}{|c|}{ Electricity (MWh) } & \multicolumn{3}{|c|}{ Natural gas (MWh) } & \multicolumn{2}{|c|}{$\begin{array}{c}\text { District heating } \\
\text { (MWh) }\end{array}$} & \multirow[b]{2}{*}{ 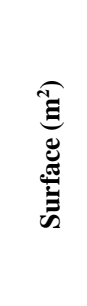 } \\
\hline & ¿ & 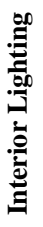 & 总 & $\underset{\Xi}{\mathscr{E}}$ & 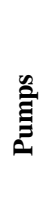 & & 㒸 & 莺 & 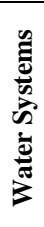 & : & 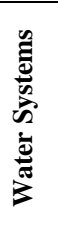 & \\
\hline $\begin{array}{c}\text { DES3 PV } \\
\text { DE }=0\end{array}$ & 0 & 0 & 0 & 0 & 0 & 0 & 0 & 0.64 & 0 & 0 & 0 & 20,200 \\
\hline
\end{tabular}

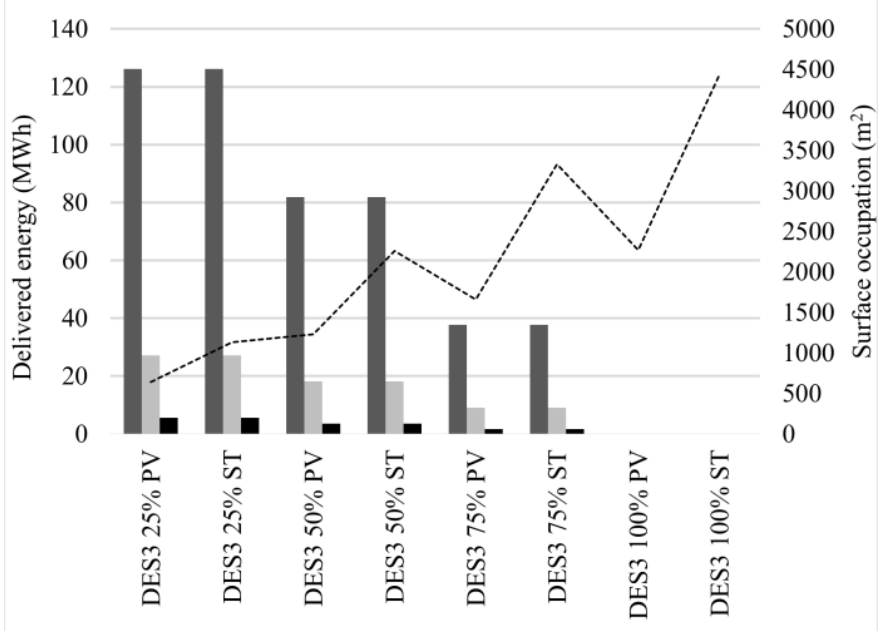

District Heating for Heating -District Heating for Water Systems

Electricity for Cooling

---Surface occupied by PV panels

Fig. 6. Delivered energy and surface occupation with solar systems.

Table VII and Fig. 6 show the results obtained. For the calculations, perfect storage (no thermal losses) for hot water was considered, and ideal electricity interchange (no limits of power and no distribution losses) with the grid was supposed.
The photovoltaic solution, in comparison with the solar thermal strategy, requires a smaller panel surface for satisfying the needs of the building. From this perspective, photovoltaic is preferable, but it could be convenient to maintain some solar thermal panels only for the DHW system, in order to remove this load from the hot water heat pump.

In order to cover all the electrical needs of the building using the PV system (scenario DES3 PV DE =0), the panel surface required would grow to about $20,200 \mathrm{~m}^{2}$, an excessive value, compared to the average floor area of the Turin Energy Centre (about 1,700 $\mathrm{m}^{2}$ ). Table VIII and Fig. 7 show the results and a comparison with the others PV scenarios.

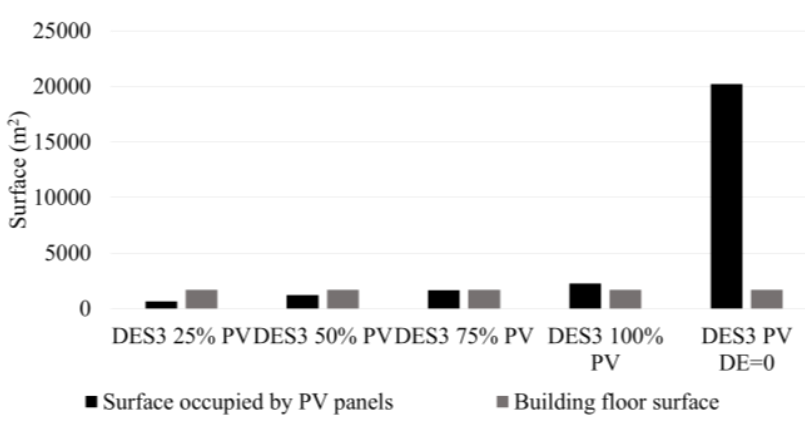

Fig. 7. Occupied surface for different solar photovoltaic configurations. 


\section{B. Approach 2: cogenerator}

The installation of a cogenerator was also considered in order to produce hot water and electricity (scenario DES3 COG). Hot water will feed the absorption refrigerator (during summer), the heating system (during winter) and the DHW (during the whole year); electricity will cover the energy consumptions of interior lighting and equipment, so that the delivered energy required by the building would be reduced only to the natural gas for feeding the cogenerator and the gas for interior equipment. The delivered power peak (that is at the same time both electrical and thermal, table IX) was identified in order to optimally size the machine, by considering some commercial models (ESS CHP units, Viessmann [11], Fig. 8). The models considered produce high temperature hot fluid $\left(120^{\circ} \mathrm{C}\right)$, suitable for the absorption refrigerator.

TABLE IX

CALCULATION OF THE THERMAL-ELECTRICAL RATIO

\begin{tabular}{|l|c|c|c|}
\hline & Electrical power & Thermal power & $\begin{array}{c}\text { Thermal- } \\
\text { Electrical ratio }\end{array}$ \\
\hline $\begin{array}{l}\text { DES3 COG } \\
\text { delivered power } \\
\text { peak (kW) }\end{array}$ & 248.5 & 433.4 & 1.744 \\
\hline $\begin{array}{l}\text { DES3 COG } \\
\text { delivered energy } \\
\text { (MWh/year) }\end{array}$ & 861.2 & 447.6 & 0.520 \\
\hline
\end{tabular}

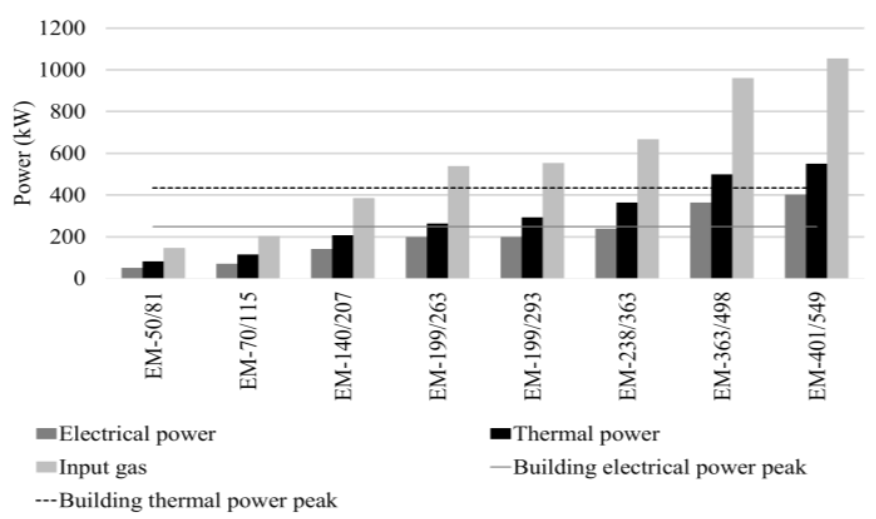

The last two models shown in Fig. 8 could be suitable for our case study, but it was decided to choose the EM-363/498 model, because the EM-401/549 was oversized.

However, it is important to underline that the cogenerator is well sized for peaks (both thermal and electrical), but not for the average working conditions; in fact, the required thermalelectrical ratio decreases a lot considering annual energy needs. Therefore, the machine will be set on the electrical power and its thermal power will be oversized.

\section{FINAL COMPARISON}

At the final stage, the PV approach was compared with the cogenerator strategy in terms of total primary energy consumptions, $\mathrm{CO}_{2}$ emissions and surface occupation (Table $\mathrm{X})$. In order to fairly compare the two scenarios in terms of primary energy consumption, we considered the photovoltaic configuration that covers all the electrical needs (Table VIII), so that both configurations (photovoltaic and cogenerator) satisfy the building's energy needs. Moreover, both in the $\mathrm{CO}_{2}$ and in the primary energy comparison, the production process of the photovoltaic panels was taken into consideration.

TABLE X

COMPARISON: PHOTOVOLTAIC - COGENERATOR

\begin{tabular}{|l|c|c|c|}
\hline & $\begin{array}{c}\text { Total primary } \\
\text { energy } \\
\text { consumption } \\
\text { (MWh/year) }\end{array}$ & $\begin{array}{c}\text { Total CO } \\
\text { emission } \\
\text { (kg/year) }\end{array}$ & $\begin{array}{c}\text { Surface } \\
\text { occupation }\left(\mathbf{m}^{2}\right)\end{array}$ \\
\hline DES3 PV DE =0 & 50.84 & 15,965 & 20,200 \\
\hline DES3 COG & 2278 & 462,467 & $<100$ \\
\hline
\end{tabular}

As said before, the surface required by PV panels is not available in the surroundings of the building. However, as in this approach the primary energy consumption and the $\mathrm{CO}_{2}$ emissions would be remarkably low, it is therefore convenient to use photovoltaic until the available surface area is covered $\left(1,500 \mathrm{~m}^{2}\right.$, estimated) and then to integrate the cogenerator.

Fig. 8. Cogenerator: peak power matching.

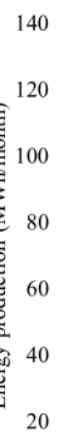

0 - - IIIIIII. - -

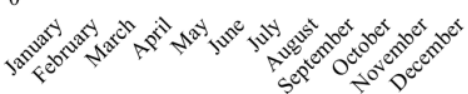

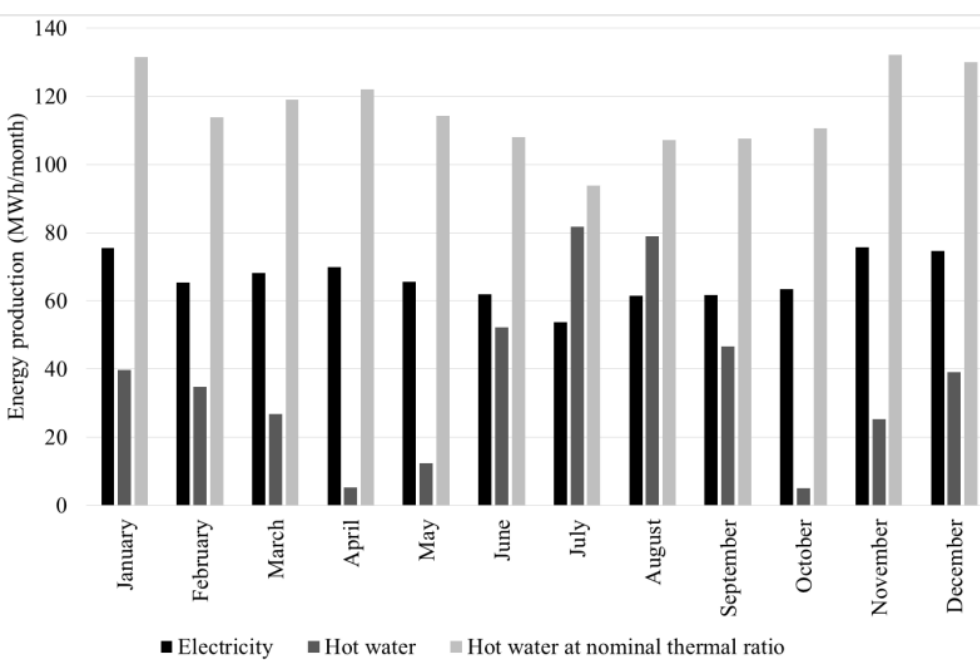

Fig. 9b. Cogenerator production profile.

Fig. 9a. Solar photovoltaic production profile. 


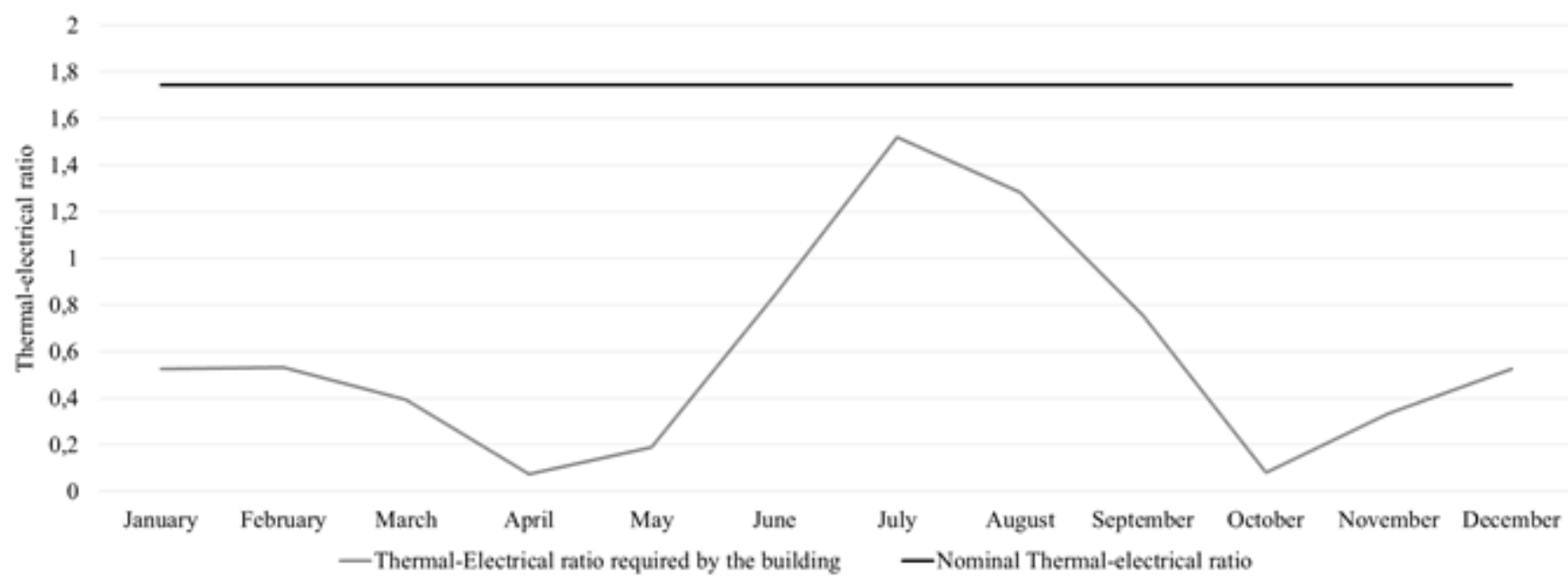

Fig. 10. Comparison between the thermal-electrical ratio requested by the building and the nominal ratio of the machine.

In this "hybrid configuration" (DES3+PV/COG), the photovoltaic panels will provide only a part of the electricity for interior lighting and equipment, reducing the electrical load of the cogenerator, thus minimizing the oversizing of its consequent thermal production

Fig. 9a and Fig. 9b display the production profiles; whereas Table XI shows the total primary energy supply and the overall $\mathrm{CO}_{2}$ emissions of the hybrid approach (hypothesis of constant thermal/electrical ratio even if the electrical load changes and perfect thermal and electrical storages) in comparison with the designed scenario DES3.

TABLE XI

COMPARISON: HYBRID - DESIGNED CONFIGURATION

\begin{tabular}{|l|c|c|}
\hline & $\begin{array}{c}\text { Total primary } \\
\text { energy consumption } \\
\text { (MWh/year) }\end{array}$ & $\begin{array}{c}\text { Total CO } \mathbf{C O}_{2} \text { emission } \\
\text { (kg/year) }\end{array}$ \\
\hline DES3+PV/COG & 2108.86 & 428,099 \\
\hline DES3 & 2339.59 & 446,921 \\
\hline
\end{tabular}

In spite of the improvement highlighted in Table XI, there are still some problems, as shown in Fig. 10. The thermalelectrical ratio requested by the building varies during the year and, monthly, it does not match with the nominal ratio of the machine. Considering setting the cogenerator in order to cover the electrical load (which is roughly constant during the year), the average thermal production will be excessive (assuming that the thermal/electrical ratio is constant with the regulation and constant efficiencies even with partial loads). It would be suitable to use a cogenerator able to calibrate the thermal power widely, whilst maintaining the electrical production constant.

In order to get a better thermal/electrical matching, we can suppose to sell excess heat to the district heating grid during winter and to use it for cooling in summer. In the intermediate seasons, the same cogenerator could be used at low speed (assuming thermal/electrical ratio constant with regulation) and the remaining electricity could be bought from the grid; alternatively, it could be suitable to adopt a smaller backup cogenerator.

\section{CONCLUSIONS}

In conclusion, it is clear that sizing the energy supply and its generation system requires great attention to the functions of the building. The hybrid configuration that was achieved (DES3+PV/COG) could make the building "autonomous" in the sense that energy could be generated locally, without depending on district heating. This solution allows an additional output (selling the excess heat to the district heating), minimizes $\mathrm{CO}_{2}$ emissions and primary energy supply (given the above-mentioned hypotheses). Above all, it gives a strong message to the people that will crowd the Turin Energy Centre: TEC, in fact, should be an example and a landmark in terms of energy efficiency and, ultimately, of environmental sustainability. 
TABLE XII

RESUME OF SYSTEM SCENARIOS

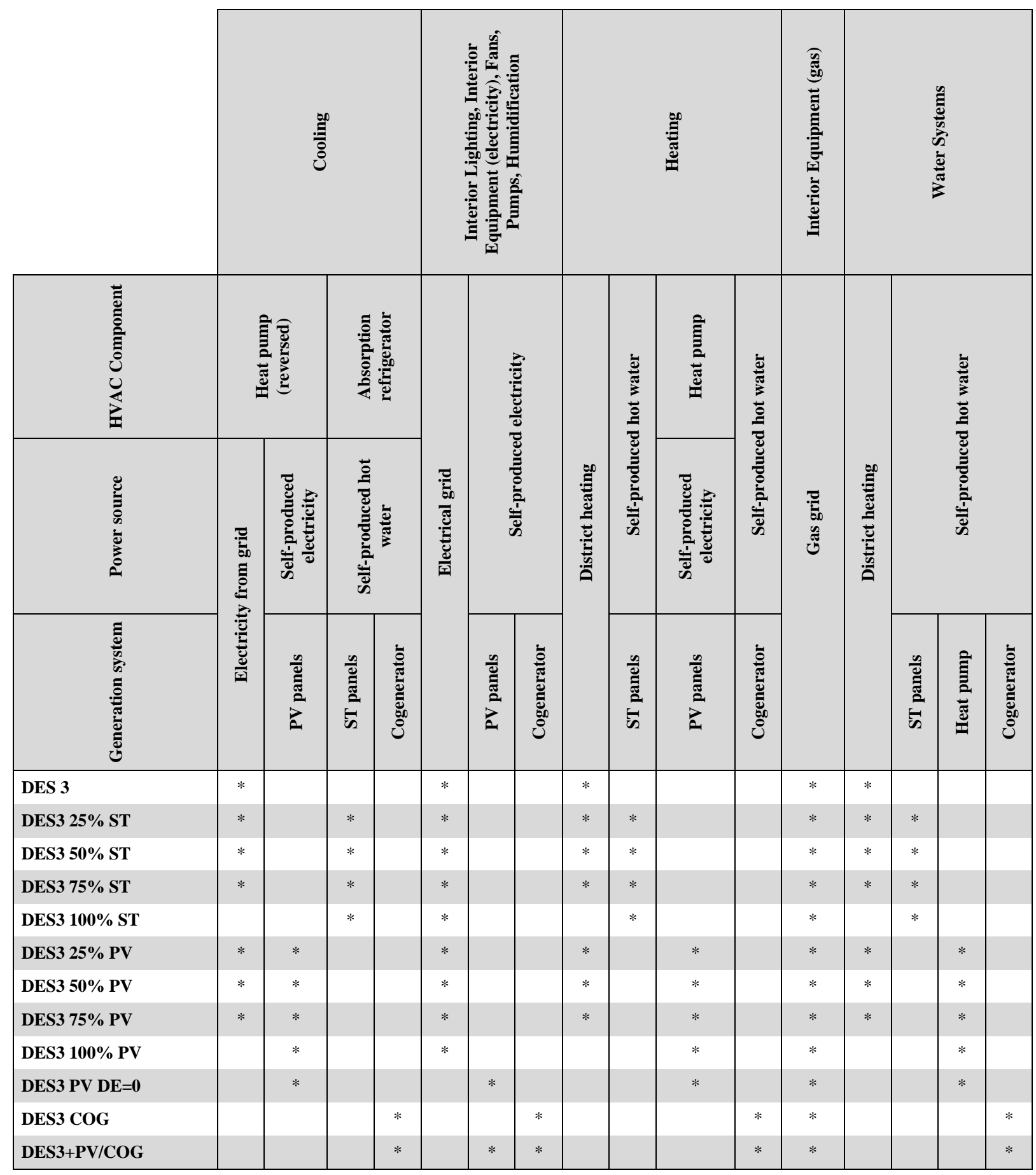




\section{ACKNOWLEDGEMENT}

This paper has been developed in the framework of the activity developed by the TEC project team of Alta Scuola Politecnica.

\section{REFERENCES}

[1] Standard ASHRAE 189.1 - 2009. Standard for the Design of HighPerformance Green Buildings.

[2] Comune di Torino, procedura aperta 83/2013. Progetto definitivo. Legge 9 Gennaio 1991, n. 10. Relazione tecnica. DGR 46-11968/2009D.Lgs. n. 311/2006 - Allegato E.

[3] Comune di Torino, procedura aperta 83/2013. Progetto definitivo. Stratigrafie murature.

[4] Comune di Torino, procedura aperta 83/2013. Progetto definitivo. Particolare serramenti e vetraggi.

[5] Comune di Torino, procedura aperta 83/2013. Progetto definitivo. Valutazione di sostenibilità ambientale Itaca. Relazione tecnica.

[6] Comune di Torino, procedura aperta 83/2013. Progetto definitivo impianti elettrici. Relazione tecnica e di calcolo.
[7] Comune di Torino, procedura aperta 83/2013. Progetto definitivo impianti termomeccanici. Relazione tecnica e di calcolo.

[8] Regione Piemonte. Deliberazione della Giunta Regionale 4 agosto 2009, n.43-11965. Legge regionale 28 maggio 2007 n. 13 (Disposizioni in materia di rendimento energetico nell'edilizia) articolo 6 e articolo 21, comma 1, lettere d), e) ed f) DISPOSIZIONI ATTUATIVE IN MATERIA DI CERTIFICAZIONE ENERGETICA DEGLI EDIFICI

[9] Provincia di Trento. Allegato I: Allegato integrativo dell'Allegato A alle "Disposizioni regolamentari in materia di edilizia sostenibile in attuazione del titolo IV della legge provinciale 4 marzo 2008, n. 1 (Pianificazione urbanistica e governo del territorio)", approvato con DPP 13 luglio 2009, n. 11-13/Leg.

[10] Aleo Solar, Modulo fotovoltaico aleo S18 [Data sheet, Online] Available: http://www.aleosolar.it/fileadmin/datenblaetter/S18/S18J43_245-265W_IT.pdf [Accessed: Nov. 29, 2014]

[11] ESS Energie Systeme \&Service GmbH, CHP units for heat and power [2013 catalogue, Online]. Available: http://www.viessmann.com/com/content/dam/internetglobal/pdf_documents/com/brochures_englisch/ESS_CHP_units.pdf [Accessed: Nov. 29, 2014] 